\title{
Contributing Factors in the Use of Leverage in Islamic Banks
}

\section{Zahid ur Rehman Khokher}

Institute of Isalmic Banking and Finance, International Islamic University

Malaysia

*Corrosponding author's Email: zaahid@gmail.com

Peer-review under responsibility of $4^{\text {th }}$ Asia International Conference 2018 editorial board (http://www.utm.my/asia/our-team/) (C) 2018 Published by Readers Insight Publisher, lat 306 Savoy Residencia, Block 3 F11/1,44000 Islamabad. Pakistan, info@readersinsight.net 


\section{Rese a r ch High Iights}

This paper aims to apply the theories on firm and bank capital structure on Islamic banks and identify contributing factors that are signficant in the use of leverage in Islamic banks. For this purpose, a 10-year panel data of 34 listed Islamic banks from 12 countries is used. In addition to studying the significance of several contributing factors for the use of debt that have been found to signficantly influence the leverage in conventional firms and banks (Frank \& Goyal, 2009; Sorokina, 2014) and Islamic banks (Bitar, Kabir Hassan, \& Hippler, 2018; Thabet, Shawtari, Ayedh, \& Ali, 2017) in past studies, several additional potential factos unique to Islamic banking business or related to legal and regulatory environement in the jurisdiction are tested. The results showed that standard coporate finance factors for leverage are applicable on Islamic banks. Similarly, Islamic banks with low profitability and earning volatility as well as high collateral and growth propects have higher leverage. It is observed that share of investment accounts in liabilites, regulations and debt market conditions are also signficant factors.

\section{Research Objectives}

The objective of paper is to empirically test the factors on Islamic banks that have been found to significantly impact the use of leverage in conventional firms and banks in line with several prominent capital structure theories. For this purpose, three alternative definitons of leverage are used: book leverage, market leverage and a newly introduced specification of 'Islamic banking leverage' that considers the impact of investment accounts along with shareholder's equity. A number of new idiosyncratic as well as legal and regulatory environment related factors are also introduced in the model to test their signficance.

The paper offers both theoretical and practial insights on Islamic banks' leverage decisions in several wasy: It uses an extensive data collected from market based and financial indicators of Islamic banks operating in the Middle East, North Africa, Asia and Europe, which enables the testing of factors such as market-to-book ratio, dividend, risk and market leverage. Similarly, the addition of factors related to idiosyncratic and regulatory specificities unique to Islamic banking business such as - share of profit sharing investment accounts in liabilites, availability of Shari'ah compliant deposit insurance scheme and regulatory requirements related to risk absorbency of investment accounts, commodity murabahah deposits and use of debt based Tier 2 Sukuk - offer new insights on Islamic bank leverage decisions. 


\section{Methodology}

The empirical analysis of capital structure theories requires a wide range of market-based, accounting and regulatory indicators from publicly listed institutions. Accordingly, this study attempts to collect yearly data of 34 listed and publicly traded Islamic banks from 12 countries, covering a period of 2008 to 2017. Islamic commercial banks that are either full-fledged banks or independent subsidiaries of conventional banks are included, whereas Islamic investment banks and Islamic windows of conventional banks are excluded. Using both OLS and Mestimators, a mutlivariate regression is estimated, with the addition of some macroeconomic variables. The behaviour of lslamic banks' leverage factors on the information asymmetry observed in systemically important banks(is seperately studied vis-à-vis smaller Islamic banks as it is assumed that the perception of large banks of obtaining government support incentivises them to increase their leverage un-proportionately (Shin, 2011). Therefore, using a dual criteria to identify domestic systemically imporant banks (asset size more than USD 3 billion and higher than $1.5 \%$ of the GDP of respective home jurisdiction), full model specification is tested by dividing the sample into two catergories. This study performes Variance Inflation Factors and pairwise correlation to check the presence of multicollinearity.

\section{Results}

The results lead to several noteworthy findings and extend the literature on bank capital strucrure and emerging markets: Standard corporate finance factors that influence capital decisions in conventional firms and banks are also important factors for Islamic banks in deciding their leverage. These include indicators computed from stock market data such as market-to-book ratio, dividend and earning volatility as well as accounting baced indicators such as profitability and collateral. Moreover, looking at the application of capital structure theories, it is evident from the results that a majority of significant factors such as size, dividend, risk, inflation and depreciation are influenced by the trade-off theory (Kraus \& Robert H. Litzenberger, 1973). However, some factors such as market-to-book ratio and profit also show signs of pecking order theory by (Donaldson, 1961, 1962). The model fits better for market leverage and Islamic banking leverage defintions than book leverage as dependent variable. It is also evident from the results that earning volatility as well as legal and regulatory framework have more significant influence on systemically important banks than they do for 


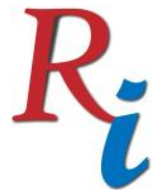

\section{Asia Proceedings of Social Sciences \\ (APSS) \\ www.readersinsight.net/APSS}

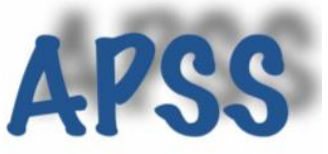

smaller, less significant banks. The paper also finds the evidence that macroeconomic factors such as GDP growth are significant for Islamic banks.

\section{Findings}

Findings of this paper demonstrate that leverage decisions in Islamic banks are impacted by their funding structure and off-balance sheet items. Moreover, regulatory environment specifically, availability of Shari'ah compliant deposit insurance has a significant impact on Islamic banks in their decision-making process for raising debt. These findings have important policy implication which offer insights to banking sector and capital market regulators, Islamic finance standard setting bodies such as IFSB and Islamic banks on key factors that influence capital structure decisions in these banks. The findings of this paper also extend the literature on emerging markets as sample countries are part of developing and emerging markets mainly in Asia, Africa and Middle East.

\section{References}

Bitar, M., Kabir Hassan, M., \& Hippler, W. J. (2018). The determinants of Islamic bank capital decisions. Emerging Markets Review, 35, 48-68. http://doi.org/10.1016/j.ememar.2017.12.002

Donaldson, G. (1961). Corporate Debt Capacity: A Study of Corporate Debt Policy and the Determination of Corporate Debt Capacity. Division of Research, Graduate School of Business Administration, Harvard University.

Donaldson, G. (1962). New Framework for Corporate Debt Policy. Harvard Business Review.

Frank, M. Z., \& Goyal, V. K. (2009). Capital Structure Decisions : Which Factors Are Reliably Important? Financial Management, 38(1), 1-37. Retrieved from http://onlinelibrary.wiley.com/doi/10.1111/j.1755-053X.2009.01026.x/epdf

Kraus, A., \& Robert H. Litzenberger. (1973). A State-Preference Model of Optimal Financial Leverage. American Finance Association, 28(4), 911-922.

Shin, H. S. (2011). Macroprudential policies beyond Basel III. In Macroprudential regulation and policy (Vol. 60, pp. 5-15). Bank for International Settlements. Retrieved from http://ideas.repec.org/h/bis/bisbpc/60-02.html

Sorokina, N. Y. (2014). Bank Capital and Theory of Capital Structure. Kent State University, 


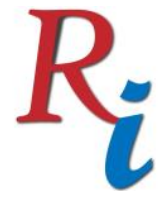

Asia Proceedings of Social Sciences

(APSS)

www.readersinsight.net/APSS

Ohio,

USA.

Retrieved

from

https://etd.ohiolink.edu/pg_10?0::NO:10:P10_ACCESSION_NUM:kent14027 95531

Thabet, O. Bin, Shawtari, F. A., Ayedh, A. M., \& Ali, F. (2017). Capital Structure of Malaysian Sharī'ah-Compliant Firms. JKAU: Islamic Economics, 30(1), 105-116. 